\title{
The Application of English Movies in English Teaching
}

\author{
Yan Chen \\ Feixian Brach, Linyi University \\ Feixian, Shandong, China, 273400 \\ e-mail:mxh399@126.com
}

\begin{abstract}
English films are vivid and can help students improve their listening, speaking abilities, strengthen language sensitivity, raise the literary accomplishment, learn more about western cultures and cultivate study interests. At present, English movies are more and more used in English teaching. In this paper, the author will discuss the importance to English study and the common problems for English teaching as well as matters needing attention when make full use of the functions of English movies in English study.
\end{abstract} study

Keywords-English film; English teaching; college English

\section{The Role OF ENGLISH MOVIES IN ENGLISH LEARNING}

Film is the enrichment of life, and also the art of reproduction of life. At the same time, it can vividly reflect all aspects of social life, and can bring people the auditory and visual enjoyment. In order to draw the students' attention, film teaching makes full use of the rich contents and various forms of the film itself and arouses the enthusiasm of students' visual and auditory ability. Besides, it also can transform simple words into intuitive language. In short, film teaching can create the environment to learn a language, in which English learning becomes a kind of natural communicated activity. Then, students consciously involved in the English teaching, so as to improve the students' interest in learning and practical ability to use English. The major benefits of using film teaching are as follows:

\section{A. Improve listening comprehension and oral English}

Once in an English match, a little girl made a great surprise to all the audience. Her spoken English was so fluent. People wanted to know how she practiced her oral English in her daily life. The little girl replied: "I like watching English movies. They can make me happy and can improve my listening and speaking abilities."

As film words are more vividly, students can easily remember how to use them and imitate the dialogues; try to taste the pronunciation and intonation in the real context of words. However, the pronunciation and intonation are lubricant for speaking fluent English. Students will never feel the strong shock which intonation rhythm showed the huge function in the film while reciting the words or listening the text of English book.

\section{B. To accumulate vocabularies and idioms}

In the movie, the vivid plots and real context can help audience remember a lot of words and sentences. We remember not only its meaning but also the corresponding use method. Besides, such memory is clear and hard to forget. Words and phrases in life appear in the film, including a lot of slang and colloquial. Only in the real context can we realize its appropriate meaning. For example, dialogue in the movie Seattle Sleepless:

Walter: Who is married to Harold? Who ran off with his secretary?

Annie: But came back because Irene threatened to put the dog to sleep if he didn't.

"Put the dog to sleep" the surface meaning of this sentence is "get the dog to sleep".

In fact the dog here is not referring to an animal. Dog in American slang can mean ugly woman. So, Annie here means "to kill that woman".

Watching a film can not only accumulate words of life but also can help English learners remember some uncommon, complicated vocabulary as well as some idioms. English learners can choose the type of movie according to their own needs.

\section{Understand the British and American culture}

Compared with other teaching aids, film has unique advantage in introducing British and American culture. Through the scene, students can visually see the foreign geographical conditions, social customs, and foreign characters etc. Intentionally or not, English national values, beliefs, feelings of the world are conveyed by the film. For example, Gone with the Wind introduced the American Civil War; American Beauty expressed emotional confusion of American people; film Forest Gump is a chronicle of the United States. Almost all the historical events are shown in the film, such as: "the Ku Klux Klan", "American Civil War ", " sexual revolution ", "", "black movement", "Vietnam war", "Watergate scandal", etc. In addition, some living conditions and social phenomenon are referred in the movie, such as "school bus" "single-parent families", "football", "American kindergarten, primary school and university," and so on. It is no doubt that this video is listed as one of the 
most popular films for college students. Therefore, by watching English movies, students can better understand the foreign culture and avoid communication barriers, to a certain extent.

\section{To develop interest in English}

Students are fond of watching movies, for the movie provides the sense of vision and auditory enjoyment. Audience can not only hear the sound of the characters, observe their actions but also can enjoy the beautiful scenery and music in a film. All of these can activate the enthusiasm of the students; make them in a relaxed and happy environment, imperceptible access to rich knowledge, and gradually like English. Sometimes a teacher babbled a lesson would not leave a deep impression to the students. However, students can taste a good movie for a long time, or even for their whole life.

\section{COMMON Problems By USING ENGLISH MoviE IN COLLEGE TEACHING}

Every coin has two sides. There are a lot of advantages for film teaching, while at the same time appear some problems. Watching a movie during the class will become a form without any help of teaching if teachers misused the movie in class. It means that the effect of watching a movie was less than expected. What are the roots of the problems?

First, it's very hard for an English teacher to arrange a proper time to enjoy a whole movie. It will cost two or three hours for a wonderful film. It's better for English major students, for they have audio-visual speaking lessons every week. But the non- English major students who only use class time is obviously not enough. They had to use time out of class. It's very difficult to make a unified arrangement for the teacher. Furthermore, appreciating and discussing the film asked more available time to use. Second, how to choose a proper movie for all the students is a question. The level of the students, the preference of the appreciation types and the existing resources determined the type of movie to choose. Nevertheless, students even in the same class have different level and preference; besides, the existing resources are limited. Moreover, how to ensure that the vast number of students can benefit from it, rather than regard it as a simple film, ignore the purpose of learning. This asked teachers to have higher professionalism to organize and plan carefully. Under teacher's guidance, students can be helped to develop good study habits. Only in this way can teacher achieve his ends.

Several aspects should be paid attention to during film teaching for a teacher.

\section{The PoInts For AtTENTION DURING THE TEACHING BY FILM}

\section{A. Material selections}

Teachers should carefully choose simple plot and standard pronunciation films which can meet the students' interest. Of course, the film content should be healthy and positive. According to investigation, most students like watching life humorous film, in which can receive spiritual enlightenment. To avoid violence, pornographic films which may have a bad effect on students. Consider the origin of the film is necessary. To avoid arcane pronunciation films although they are English movies. By comparison, film pronunciation in Europe and the United States is standard. It can be used as study material. Actors, such as Mag Rain, Julia Roberts, Tom Hanks, their pronunciations are much articulate and standard. So, their movies can be recommended to imitate to study.

\section{B. Reasonable arrangement of time}

Non-English major students rarely have a particular time of seeing and hearing class.At the same time, class time is so limited that an English teacher is impossible to use the whole day time to appreciate the film. Therefore, teachers should manage self-study time and extracurricular time to fish the film. Arrangement in the evening is the best way, so that students can fully input in the movies after a busy day. Meanwhile, the effect of the multimedia in the evening is best. The last but not the least, students can timely review film content and deepen the impression by dormitory chatting when they finish the film and go back to their dorms. Besides the proper time, reasonable frequency of the movie should also be paid attention to. How often is the most reasonable? The answer may be once a month. Of course, the students also can choose other ways to see the film according to their circumstance.

\section{Design good movie teaching steps}

Film teaching is definitely not the teacher only responsible for students to choose a movie to see without do any guidance. If in that way, students will only consider the movie as a general entertainment. Film teaching will not work. Therefore, the teacher should be a good guider during watching a movie, not only arrange good movie teaching, but also strengthen students' appreciation.

It can be divided into three links during the film teaching: movie before, enjoy movies, and after watching movies. In the first link, teachers should choose the movies for teaching as well as the time and place to watching according to the actual circumstance of students. During the second link of the process of the movie, teachers should give the students some information prompt mainly in the field of play before, such as set the keywords, introduce the plot, or give some questions etc. This link is very important for understanding the film. During enjoying the movie, teachers should better require students to take notes, write down the film of the words, idioms, slang, good expressions, information, and encourage the students to read and imitate the classic sentences or standard pronunciation. The third link is mainly for feedback, and learning effect. Teachers can use the ways such as Fill Blanks and Answer the Questions, Discuss, Report, and Act Out to test students' understanding of the film. Teachers should attach great importance to the role of the link. 


\section{CONCLUSION}

To sum up, the use of films in English teaching is an effective teaching method. It can not only arouse the enthusiasm of students in learning English, improve the level of listening, speaking, but also lead a way to know British and American culture. At the same time, students obtained artistic edification. However, film teaching problems may be occurred during the teaching. Teachers should give full play to the role of the lead, scientifically design the teaching ideas, and help students form good learning habits. Only in this way can the advantages of English movies play, and help students obtain the comprehensive language skills and communication skills.

\section{REFERENCES}

[1] Lihong. Learning Autonomy and China's English Teaching [J] Foreign Language Teaching and Research, 1999,(10)

[2] Xiaya Jun. Investigation on English Original Film Teaching [J] Generation of Network Technology 2007,(20)

[3] Liangxiang Dong. How to Improve English Teaching Effect,[J] Education Innovation, 2007,(5)

[4] The Development of Language Sense in College English Teaching [J] Higher Education Research,2014,(10) 